\title{
Nutritional Status of Pregnant Women and Newborns in a Secondary Referral Health Care Setting of India
}

\author{
Mohanraj Rathinavelu Mudhaliar,1,2, Ishrar Shaik Mohammad Ghouse ${ }^{1,2}$, Jagadeesh Neppali ${ }^{3 *}$, Divya \\ Asavadi ${ }^{4}$, Veerendra Uppara ${ }^{4}$, Vidyasagar Chinnakotla ${ }^{4}$
}

1'Division of Pharmacy Practice, Raghavendra Institute of Pharmaceutical Education \& Research RIPER, Anantapuramu, Andhra Pradesh, INDIA.

${ }^{2}$ Drug Information Pharmacist, Poison and Drug Information Centre, Department of Pharmacy Practice, RDT Hospital, Bathalapalli, Anantapuramu, Andhra Pradesh, INDIA.

${ }^{3}$ Clinical Pharmacologist, FORTIS Hospital, Fortis Healthcare Limited, Mulund, Mumbai, INDIA.

${ }^{4}$ Resident Intern, VI Year Pharm D, Division of Pharmacy Practice, Raghavendra Institute of Pharmaceutical Education \& Research RIPER, Anantapuramu, Andhra Pradesh, INDIA.

\begin{abstract}
Background: Maternal nutrition status is an important determinant of pregnancy outcomes since pre-pregnancy underweight has been traditionally considered a risk factor for adverse gestation outcomes. Objectives: The current study aims to offer updated information on the nutrition status of pregnant women and newborns to facilitate the development of health care protocols based on current knowledge. Materials and methods: The current prospective, observational study of six months descriptively assessed the nutrition status in a cohort sample of 220 pregnant women, in which vital parameters, treatment, laboratory parameters, anthropometric details, food habits and intake were obtained and documented during their regular clinical visits. During the study period all the health information's were documented and assessed. Statistical tool used was WHO Nutri Survey 2007 calculator. Results: The study observed nearly $80.45 \%$ of pregnant women were within age group of 20-30 years, illiteracy population was $35.45 \%$. In our study, $78.19 \%$ of pregnant women were anaemic, and an overall distribution of $60.45 \%$ pregnant women within BMI of $18.5-25$. In the present study the mean \pm SD calorie and protein intake of the study subjects per day was found to be $1839.8 \pm 250.2 \mathrm{Kcal}$ and $63.1 \pm 7.2$ g. The prevalence rate of low birth weight during the study period was $87.43 \%$. Conclusion: Low birth weight in India has been attributed to widespread maternal undernutrition. A better understanding of the relationship of birth size to maternal nutrition is critical for planning effective intervention to improve birth weight in Indian babies unless we perform extensive researches.
\end{abstract}

Key words: Pregnant women, Newborns, Nutritional status, Maternal nutrition, Undernutrition, Low birth weight, Anaemia.

\section{INTRODUCTION}

Maternal nutrition and health is considered as the most important regulator of human fetal growth. Improved maternalnutrition hasbeen associated with increased fetal growth and a reductionin adverse birth outcomes in developing countries and in populations with nutrient deficiencies. ${ }^{1,2}$ However, if women are not well nourished, they are more likely to give birth to weak babies resulting in high infant mortality rate. ${ }^{3}$ At birth, fetal weight is accepted as the single parameter that is directly related to the health and nutrition of the mother, and on the other hand, is an important determinant of the chances of the newborn to survive and experience healthy growth and development. This is because low birth weight has been shown to be directly related to both immediate, long-term and very longterm development and well-being. ${ }^{4}$

Nutritional requirements may change based on maternal age, which may impact maternal nutritional status and milk composition
DOI: 10.5530ijopp.10.1.5

Address for correspondence: Dr. Jagadeesh Neppali. Pharm. D,

Clinical Pharmacologist, FORTIS Hospital, Fortis Healthcare Limited, Mulund, Mumbai, INDIA.

Phone no: +91 8121934940

E-mail: moley4u@rediffmail.com

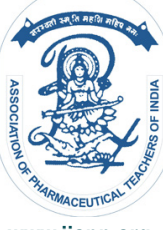

www.ijopp.org 
to varying degrees, especially in adolescent or malnourished mothers. ${ }^{5}$

Breast milk must guarantee the adequate nutrition of the infant as a continuation of intrauterine nutrition, and both the mother's nutritional status as well as her diet may influence breast milk composition and therefore nutrient intake in the infant. ${ }^{6}$ Nutritional requirements are higher in infancy than in any other stage of development, and there is evidence that the composition of breast milk changes with time to adjust to the changing needs of the child. ${ }^{7-10}$ In the event of famines and disasters, and when there is risk of child malnutrition, the approach recommended by the WHO is to support breastfeeding, which guarantees the correct development of the baby, and to supplement the diet of the mother. ${ }^{11-13}$

The age, baseline postpartum weight, level of activity and individual metabolism will influence the amount of food each woman needs to consume to achieve an optimal nutritional status and an adequate milk supply. The duration and intensity of breastfeeding also have a significant impact on maternal nutritional requirements, but are rarely taken into consideration. ${ }^{14}$

The prevalence of nutrient deficiencies varies based on geographical region, culture, dietary habits and socioeconomic level. ${ }^{15-18}$ Under-nutrition in pregnant women is associated with a range of detrimental effects to the developing fetus, including intrauterine growth retardation (under-growth) and low-birth weight. Maternal under-nutrition during pregnancy, IUGR and low birth weight are in turn associated with range adverse outcomes for the developing fetus and/or newborn baby, including an increased risk of still birth, premature birth, perinatal mortality, infant neurological, intestinal, respiratory and circulatory disorders, birth defects, underdevelopment of some organs, cretinism and brain damage. ${ }^{19}$

Micronutrient status at the time of conception is also determined by historic nutrient consumption, and deficiency in one or more micronutrients can detrimentally affect the health of the mother and her baby. ${ }^{20}$ Women who experience deficiencies in specific micronutrients before pregnancy generally have an increased risk of iron deficiency anemia, ${ }^{21}$ vitamin B12 deficiency, ${ }^{22}$ vitamin $\mathrm{K}$ deficiency, ${ }^{23}$ iodine deficiency, ${ }^{24}$ zinc deficiency ${ }^{25}$ and Magnesium deficiency.

Fetal health risks which arise as a result of deficiency on particular micronutrients includes maternal vitamin $\mathrm{D}$ deficiency associated with fetal rickets, maternal folate deficiency associated with an increased risk of neural tube defects in the infant, maternal iodine deficiency is associated with congenital abnormalities, increased risk of infant mortality, neurological cretinism, mental deficiency, Spastic diplegia and squint, myxoedymateous cretinism and dwarfism, psychomotor effect, maternal zinc deficiency associated with fetal growth retardation and congenital abnormalities. ${ }^{26}$

Although there is a vast body of literature on the physiology and disease of lactating women, the professionals that care for them often lack adequate knowledge about their nutritional requirements. ${ }^{27}$ This document aims to offer updated information on the nutrition status of pregnant women and newborns to facilitate the development of health care protocols based on current knowledge in a secondary referral healthcare setting of India.

\section{MATERIALS AND METHODS}

The current prospective, observational and descriptive study carried at a 300 bedded secondary care referral healthcare setting in the department of obstetrics and gynaecology, and department of neonatology for a period of six months of a rural and resource limited background of Andhra Pradesh., India. A structured process was followed for obtaining permission from hospital authority by submitting a detailed profoma of the study which includes protocol of study, evidence of critically evaluated biomedical literatures, data collection form, patient informed consent form. After the initial acceptance from the hospital, study was registered in the institutional review board (IRB) of the institution for ethical approval.

A total of 220 pregnant women as participants showing willingness towards the study were included and others were excluded. A documentation from (data collection form) was designed to collect the patient's information which was kept confidential, the information from patients were collected only after explaining the merits and demerits of the study and obtaining their consent for which an informedconsent form was designed separately.

After enrolling the pregnant women in to study; vital parameters, treatment, laboratory parameters, anthropometric details, food habits and food intake and cultural beliefs were obtained and documented during their regular clinical visits. Regular monitoring of BMI was done and information's on importance of nutritional values, diet and maintenance methods were recommended. The data collection continues up to delivery of pregnant women and involves the monitoring of newborns BMI values. During the study period all the health information's (progression/issues) were documented and assessed. Statistical tool used was WHO NutriSurvey 2007 calculator. 


\section{RESULTS}

The study was based on evaluating the nutritional status of 220 pregnant women regularly visiting the department of obstetrics and gynaecology of a secondary referral healthcare setting in a rural, resource limited background of India.

\section{Demographic details of study participants}

The study observed nearly $80.45 \%$ (177) of pregnant women were within age group of 20-30 years, illiteracy population was $35.45 \%$ and $63.63 \%$ of study participants were housewives and $22.73 \%$ were salaried. In our study, the first pregnancy population was $25.9 \%$ and more than 3 pregnancies were $2 \%$ and nearly $46.36 \%$ of pregnant women presented with normal delivery, results of which are summarized in Table 1. Demographic details of the study participants.

\section{Distribution of study participants based on haemoglobin levels}

\begin{tabular}{|c|c|c|c|}
\hline S.no & Demographic details & Number & $\%$ \\
\hline \multicolumn{4}{|c|}{ Age distribution } \\
\hline 1 & $<20$ & 9 & 4.1 \\
\hline 2 & $20-30$ & 177 & 80.45 \\
\hline 3 & $30-40$ & 28 & 12.73 \\
\hline 4 & $>40$ & 6 & 2.72 \\
\hline \multicolumn{4}{|c|}{ Education qualification } \\
\hline 5 & Illiterates & 78 & 35.45 \\
\hline 6 & Primary school & 21 & 9.54 \\
\hline 7 & Upper primary school & 33 & 15 \\
\hline 8 & Matriculation & 48 & 21.82 \\
\hline 9 & Inter & 14 & 6.36 \\
\hline 10 & Degree/ B. Tech & 15 & 6.82 \\
\hline 11 & Other (MBA, MSc) & 11 & 5.01 \\
\hline \multicolumn{4}{|c|}{ Employment / Occupation } \\
\hline 12 & House wife & 140 & 63.63 \\
\hline 13 & Salaried & 50 & 22.73 \\
\hline 14 & Self employed & 30 & 13.64 \\
\hline \multicolumn{4}{|l|}{ Parity } \\
\hline 15 & 0 time & 57 & 25.91 \\
\hline 16 & 1 time & 110 & 50 \\
\hline 17 & 2 times & 34 & 15.45 \\
\hline 18 & 3 times & 14 & 6.36 \\
\hline 19 & $>3$ times & 5 & 2.27 \\
\hline \multicolumn{4}{|c|}{ Delivery status } \\
\hline 20 & Normal & 102 & 46.36 \\
\hline 21 & Caesarean & 97 & 44.09 \\
\hline 22 & Follow of failure & 21 & 9.55 \\
\hline
\end{tabular}

In our study, the pregnant women were grouped as anaemic and non-anaemic based on their haemoglobin levels as per the Indian Council of Medical Research Categories of anemia, ${ }^{28}$ were we observed $78.19 \%$ of pregnant women are anaemic (based on haemoglobin level $<10.9 \mathrm{mg} / \mathrm{dL}$ ) and $21.81 \%$ were non anaemic are summarized in Table 2. Distribution of study participants based on haemoglobin levels.

\section{Distribution of study participants based on BMI and anaemia}

Our study observed an overall distribution of $60.45 \%$ pregnant women within BMI of 18.5-25, followed by $23.63 \%$ women $<$ BMI of 18.5 and $15.91 \%$ of women $>$ BMI of 25 , in which $64.53 \%$ and $45.83 \%$ population of women were anaemic and non anaemic within BMI of 18.5-25, results of which are summarized in Table 3. Distribution of study participants based on BMI and anaemia.

\section{Nutritional intake in study participants}

Table 4. Nutritional intake of pregnant women with reference to RDA (ICMR), 2009summarizes the nutritional intake of study participants (pregnant women) per day in comparison to RDA values given as per ICMR 2009, which was found very less in our study.

\section{Distribution of newborns based on body weight}

Our study observed $46.36 \%$ of normal vaginal delivery, $44.1 \%$ of caesarean delivery and $12.27 \%$ of follow-

Table 2: Distribution of study participants based on haemoglobin levels $(\mathrm{N}=220)$

\begin{tabular}{ccccc}
\hline $\begin{array}{c}\text { S. } \\
\text { no }\end{array}$ & $\begin{array}{c}\text { Haemoglobin } \\
\text { levels } \\
\text { (gm/dL) }\end{array}$ & $\begin{array}{c}\text { Degree of } \\
\text { anaemia }\end{array}$ & Number & $\%$ \\
\hline 1 & $10.0-10.9$ & Mild & 59 & 26.82 \\
2 & $7.0-10.0$ & Moderate & 72 & 32.73 \\
3 & $<7.0$ & Severe & 33 & 15 \\
4 & $<4.0$ & $\begin{array}{c}\text { Very severe } \\
\text { (decompensated) }\end{array}$ & 8 & 3.64 \\
5 & $>11.0$ & Non anaemic & 48 & 21.81 \\
\hline
\end{tabular}

Table 3: Distribution of study participants based on BMI and anaemia

\begin{tabular}{|c|c|c|c|c|c|c|}
\hline \multirow[t]{2}{*}{ BMI } & \multicolumn{2}{|c|}{$\begin{array}{l}\text { Anaemic } \\
\text { population } n \\
=172\end{array}$} & \multicolumn{2}{|c|}{$\begin{array}{l}\text { Non anaemic } \\
\text { population } n \\
=48\end{array}$} & \multicolumn{2}{|c|}{ Total $n=220$} \\
\hline & Number & $\%$ & Number & $\%$ & Number & $\%$ \\
\hline $\begin{array}{c}< \\
18.5\end{array}$ & 37 & 21.51 & 15 & 31.25 & 52 & 23.63 \\
\hline $\begin{array}{r}18.5 \\
-25\end{array}$ & 111 & 64.53 & 22 & 45.83 & 133 & 60.45 \\
\hline$>25$ & 24 & 13.95 & 11 & 22.92 & 35 & 15.91 \\
\hline
\end{tabular}




\begin{tabular}{|c|c|c|c|}
\hline S.no & $\begin{array}{c}\text { Nutritional } \\
\text { intake (Per day) }\end{array}$ & $\begin{array}{c}\text { Study } \\
\text { participants } \\
\text { (Mean + S.D } \\
\text { Values) }\end{array}$ & $\begin{array}{l}\text { RDA values as } \\
\text { per ICMR, } 2009\end{array}$ \\
\hline 1 & Energy & $\begin{array}{c}1839.8 \pm 250.2 \\
\text { Kcal }\end{array}$ & $2100 \mathrm{Kcal}$ \\
\hline 2 & Protein & $63.1 \pm 7.2 \mathrm{~g}$ & $80 \mathrm{~g}$ \\
\hline 3 & Calcium & $760.9 \pm 3.4 \mathrm{mg}$ & $1300 \mathrm{mg}$ \\
\hline 4 & Magnesium & $421.3 \pm 8.6 \mathrm{mg}$ & $450 \mathrm{mg}$ \\
\hline 5 & Iron & $9.7 \pm 3.1 \mathrm{mg}$ & $18 \mathrm{mg}$ \\
\hline 6 & Zinc & $7.1 \pm 2.5 \mathrm{mg}$ & $15 \mathrm{mg}$ \\
\hline 7 & lodine & $102.3 \pm 2.5 \mathrm{mcg}$ & $150 \mathrm{mcg}$ \\
\hline 8 & Vitamin A & $4139.5 \pm 805.2 \mu \mathrm{g}$ & $8000 \mathrm{IU}$ \\
\hline 9 & Thiamine & $1.02 \pm 0.5 \mathrm{mg}$ & $1.7 \mathrm{mg}$ \\
\hline 10 & Riboflavin & $1.2 \pm 0.2 \mathrm{mg}$ & $2.0 \mathrm{mg}$ \\
\hline 11 & Niacin & $11.24 \pm 3.2 \mathrm{mg}$ & $20 \mathrm{mg}$ \\
\hline 12 & Vitamin B6 & $1.2 \pm 0.5 \mathrm{mg}$ & $2.5 \mathrm{mg}$ \\
\hline 13 & Vitamin B12 & $4.8 \pm 0.9 \mathrm{mcg}$ & $8 \mathrm{mcg}$ \\
\hline 14 & Biotin & $221.2 \pm 0.8 \mathrm{mcg}$ & $300 \mathrm{mcg}$ \\
\hline 15 & Vitamin C & $52.2 \pm 12.5 \mathrm{mg}$ & $60 \mathrm{mg}$ \\
\hline 16 & Folic acid & $211.1 \pm 35.2 \mu \mathrm{g}$ & $800 \mathrm{mcg}$ \\
\hline
\end{tabular}

Table 5: Distribution of newborns based on body weight

\begin{tabular}{cccc} 
S.no & $\begin{array}{c}\text { Body weight (in } \\
\text { Kilograms) }\end{array}$ & $\begin{array}{c}\text { Number of } \\
\text { newborns }\end{array}$ & $\%$ \\
\hline 1. & $\leq 1.0$ & 21 & 10.55 \\
2. & $1.1-1.5$ & 29 & 14.57 \\
3. & $1.6-2.0$ & 90 & 45.23 \\
4. & $2.0-2.5$ & 34 & 17.08 \\
5. & $>2.5$ & 25 & 12.57 \\
Total & 199 & 100 & \\
\end{tabular}

up failure. Out of 199 newborns only $12.57 \%$ were on normal distribution of body weight (>2.5 kilograms), results of which are summarized in Table 5. Distribution of newborns based on body weight.

\section{DISCUSSION}

Pregnancy is an anabolic process and a woman's normal nutritional requirement increases during pregnancy to meet the needs of the growing fetus and the maternal tissues associated with pregnancy. Since the nutritional status of the expectant mother is one of the most important determinants affecting pregnancy outcomes, ${ }^{29}$ good maternal nutrition is important for the health and reproductive performance of women and the health, survival, and development of their children. ${ }^{30}$ The study by Mora and Nestel $^{30}$ showed that out of 200 million pregnant women each year, many pregnant women in developing countries suffer from nutritional deficiencies and these nutritional problems affect a woman's and her newborn infant's quality of lives. Therefore to have optimal maternal as well as perinatal outcome, nutrition in pregnancy should be well-maintained. A study on dietary intake of expectant mother revealed that proper dietary balance of mother's diet is necessary to ensure sufficient energy and nutrient intake for adequate growth of the fetus without depleting maternal stores and damaging mother's own tissues to maintain her pregnancy. ${ }^{31}$

Sufficient nutrition intake during pregnancy has enormous potential for promoting the nutritional status of the mother and her child. ${ }^{32}$

Our study observed nearly $80 \%$ (177) of pregnant women were within age group of 20-30 years; these results supported the work of MB Bellad et al. 2012. ${ }^{33}$ As far as education level and occupation of study population is concerned, almost one third $(35.45 \%)$ and two third $(63.63 \%)$ of the respondents were illiterate and housewives, and our results are supported by the study carried by Yasmeen Majid Khan et al. 2012. ${ }^{34}$ High prevalence of anaemia $(78.19 \%)$ was observed in the current study where as Madhavi et al. 2011,35 Saxena et al. $2000^{36}$ and Gautam et al. $2002^{37}$ observed incidence of $66.67 \%, 36.1 \%$ and $96.5 \%$ respectively in their study. In our study, $23.63 \%$ pregnant women had BMI less than 18.5 due to rural; resource limited and reduced socioeconomic background. Similar findings were observed in Madhavi et al. $2011^{35}$ and Saxena et al. 2000. ${ }^{36}$ In the present study the mean \pm SD calorie and protein intake of the study subjects per day was found to be 1839.8 $\pm 250.2 \mathrm{Kcal}$ and $63.1 \pm 7.2 \mathrm{~g}$ which were lesser than the normal value of $2100 \mathrm{Kcal}$ energy intake and 80 $\mathrm{g}$ of protein intake per day as recommended by RDA values as per ICMR 2009 respectively. Similar finding were reported by Sachar et al. $2000^{38}$ and Metgud CS et al. 2012. ${ }^{39}$ The prevalence rate of low birth weight during the study period was observed to be $87.43 \%$. But, one study done in Ballabgarh had the prevalence rate of LBW as low as $8.8 \%$ and another study conducted in West Bengal as high as $31.3 \% .^{40,41}$

\section{CONCLUSION}

Augmentation in education and socioeconomic status are the key components of good pregnancy outcome, which are still at dwarf phase and effective antenatal care is lacking among the pregnant women, in rural and resource limited healthcare background for which a structured referral system and increased awareness in women are essential, regarding significance of maternal nutrition and risks of under nutrition. Low birth weight in India has been attributed to widespread maternal 
undernutrition. A better understanding of the relationship of birth size to maternal nutrition is critical for planning effective intervention to improve birth weight in Indian babies unless we perform extensive researches. Further, study bearing large number of study subjects shall better give insight regarding the prevalence of malnutrition. It would be even better if ambispective studies are carried out for the development of strong and proper guidelines for the prevention of supremacy in malnutrition

\section{ACKNOWLEDGEMENTS}

The authors would like to thank all medicos and allied healthcare staffs of RDT Hospital, Bathalapalli, Anantapuramu for their assistance in data collection and staffs of division of pharmacy practice, Raghavendra Institute of Pharmaceutical Education and Research RIPER for their constant support and guidance throughout the study.

\section{CONFLICT OF INTEREST}

The author declares no conflict of interest.

\section{FUNDS AND GRANTS}

NIL

\section{ABBREVIATIONS}

IUGR:Intrauterine Growth Retardation; BMI:Body Mass Index; WHO:World Health Organization; LBW:Low Birth Weight; Kcal:Kilo calories; IRB: Institutional Review Board; ICMR:Indian Council of Medical Research; RDA:Recommended Dietary Allowances.

\section{REFERENCES}

1. Fall $\mathrm{CH}$, Yajnik CS, Rao S, Davies AA, Brown N, Farrant HJ. Micronutrients and fetal growth. J Nutr. 2003;133(5):1747S-56S. PMid:12730494.-

2. Rao S, Yajnik CS, Kanade A, Fall CH, Margetts BM, Jackson AA et al. Intake of micronutrient-rich foods in rural Indian mothers is associated with the size of their babies at birth: Pune MaternalNutrition Study. J Nutr. 2001;131(4):121724. PMid:11285330.

3. Subarnalata S, Basumati P. A study of nutritional status of pregnant women of some villages in Balsore District Orissa. Journal of Human Ecology. 2006;20(3):227-32.

4. Barker DJP, Bull AR, Osmond C, Simmons SJ. Fetal and placental size and risk of hypertension in adult life. BMJ. 1990;301:259-62. https://doi. org/10.1136/bmj.301.6746.259 : https://doi.org/10.1136/bmj.301.6751.551-b ; PMid:2390618 PMCid:PMC1663477.

5. Hall MV. Nutritional status in pregnant adolescents: a systematic review of biochemical markers. Matern Child Nutr. 2007;3(2):74-93. https://doi. org/10.1111/j.1740-8709.2007.00081.x ; PMid:17355441.

6. Susana AS, José AA, Marta D-GN. The importance of maternal nutrition during breastfeeding: Do breastfeeding mothers need nutritional supplements? An Pediatr (Barc). 2016;84(6):347-e1.
7. Food and Nutrition Board, Institute of Medicine of the National Academies. Dietary reference intakes for energy, carbohydrate, fiber, fat, fatty acids, cholesterol, protein, and amino acids. Washington, D.C.: The National Academy Press; 2005.

8. Barness LA, Dallman PR, Anderson H, Collipp PJ, Nichols BL Jr, Walker WA, et al. Nutrition and lactation. Pediatrics. 1981;68:435-43.

9. Allen LH. Multiple micronutrients in pregnancy and lactation: an overview. Am J Clin Nutr. 2005;81(5):1206S-12S. PMid:15883453.

10. Allen LH. Maternal micronutrient malnutrition: effects on breast milk and infant nutrition, and priorities for intervention. SCN News. 1994:21-4. PMid:12288231.

11. Organización Mundial de la Salud. Alimentación en circunstancias excepcionalmente difíciles. Salud del recién nacido. Temas de la OMS. Available from: http://www.who.int/maternalchildadolescent/topics/newborn/ nutrition/fiedc/es/[accessed 01.09.2015].

12. Chapman DJ, Nommsen-Rivers L. Impact of maternal nutritional status on human milk quality and infant outcomes: an update on key nutrients. Adv Nutr. 2012;3(3):351-2. https://doi.org/10.3945/an.111.001123 ; PMid:22585911 PMCid:PMC3649469.

13. CJ, Wagner CL. Nutritional management of the breastfeeding dyad. Pediatr Clin North Am. 2013;60(1):261-74. https://doi.org/10.1016/j.pcl.2012.10.008 ; PMid:23178069.

14. Dewey KG. Impact of breastfeeding on maternal nutritional status. Adv Exp Med Biol. 2004;554:91-100. https://doi.org/10.1007/978-1-4757-4242-8_9 ; PMid:15384569.

15. Subcommittee for a Clinical Application Guide, Committee on Nutritional Status during Pregnancy and Lactation, Food and Nutrition Board, Institute of Medicine, National Academy of Sciences. Nutrition during pregnancy and lactation. An implementation guide. Washington, D.C.: National Academy Press; 1992.

16. Michaelsen KF, Larsen PS, Thomsen BL, Samuelson G. The Copenhagen Cohort Study on Infant Nutrition and Growth: breast-milk intake, human milk macronutrient content, and influencing factors. Am J Clin Nutr. 1994; 59:600. PMid:8116536.

17. Picciano MF. Nutrient composition of human milk. Pediatr Clin North Am. 2001;48:53. https://doi.org/10.1016/S0031-3955(05)70285-6.

18. The Standing Committee on the Scientific Evaluation of Dietary Reference Intakes and its Panels on Folate, Other B Vitamins, and Choline and Subcommittee on Upper Reference Levels of Nutrients; Food and Nutrition Board; Institute of Medicine. Dietary reference intakes for thiamine, riboflavin, niacin, vitamin B6, folate, vitamin B12, pantothenic acid, biotin, and choline. Washington, D.C.: The National Academies Press; 1998.

19. Yehuda S, Rabinovitz S, Mostofsky I. Nutritional Deficiencies in Learning and Cognition. Journal Pediatric Gastro enter Nutrition. 2006:43;S22-5.

20. Matin-Gronert MO. Maternal nutrition during pregnancy and health of the offspring. Information Processing and Molecular Signaling. 2006:34(5);779-82.

21. National Health and Medical Research Council. Iron - 2006. Available from: http://www.nrv.gov.au/nutrients/iron.htm . [Cited 2009, August 22].

22. World Health Organization. Promoting Optimal Fetal Development: report of a technical consultation - 2006. Available from: http://www.who.int/nutrition/ publications/fetal_dev_report_EN.pdf. [Cited 2010, May 2].

23. National Health and Medical Research Council. Vitamin K. - 2006. Available from: http://www.nrv.gov.au/nutrients/vitamin\%20k.htm [cited 2009, August 22].

24. National Health and Medical Research Council. lodine - 2006. Available from: http://www.nrv.gov.au/nutrients/iodine.htm [cited 2009, August 22] .

25. Black, R. Micronutrients in pregnancy. British Journal Nutrition. 2001: 85(S2); 3-7. https://doi.org/10.1079/BJN2000314.

26. United Nations ACC Sub-Committee on Nutrition. 4th Report on the World Nutrition Situation: Nutrition throughout the lifecycle -2000 .

27. Hall V, Lowe N, Crossland N, Berti C, Cetin I, Hermoso M et al. Nutritional requirements during lactation. Towards European alignment reference values: the EURRECA network. Matern Child Nutr. 2010;6(2):39-54. https://doi. org/10.1111/j.1740-8709.2010.00276.x ; PMid:22296250.

28. Indian Council of Medical Research. Evaluation of National Nutritional Anaemia Prophylaxis Programme. Task Force Study. New Delhi: ICMR 1989.

29. Ramakrishnan U. Nutrition and low birth weight: from research to practice. American Journal of Clinical Nutrition. 2004;79(1):17-21. PMid:14684392.

30. Mora JO, Nestel PS. Improving prenatal nutrition in developing countries: strategies, prospects, and challenges. Am J Clin Nutr. 2000;71(5):1353S-63S. Printed in USA. PMid:10799413.

Indian Journal of Pharmacy Practice, Vol 10, Issue 1, Jan-Mar, 2017 
31. Mridula D, Mishra CP, Chakraverty A. Dietary intake of expectant mother. Indian J Nutr Diet. 2003;40:24-30.

32. Adikari AMNT,SivakanesanRDGNG, WijesingheCL. Assessment of Nutritional Status of Pregnant Women in a Rural Area in Sri Lanka. Tropical Agricultural Research. 2016;27(2):203-11. https://doi.org/10.4038/tar.v27i2.8168.

33. BelladMB, SrividhyaK, Kangle R, DhadedSM. Factors associated with perinatal mortality: a descriptive observational study. Journal of South Asian Federation of Obstetrics and Gynecology. 2010;2(1):49-51. https://doi.org/10.5005/jpjournals-10006-1060.

34. Yasmeen MK, Asmat K. A Study on factors influencing the Nutritional Status of Lactating Women in Jammu, Kashmir and Ladakh Regions. International Journal of Advancements in Research and Technology. 2012;1(4):1-10.

35. MadhaviLH, SinghHKG. Nutritional Status of Rural Pregnant Women. People's Journal of Scientific Research. 2011;4(2):20-3

36. Saxena V, Shrivastava VK, Idris MZ, Mohan U, Bhushan V. Nutritional status rural pregnant women. Indian Journal of Community Medicine. 2000;25(3):1047.
37. Gautam VP, Bansal Y, Taneja DK, Saha R. Prevalence of anemia amongst pregnant women and its sociodemographic association in rural area of Delhi. Indian Journal of Community Medicine. 2002;27(4):157-60.

38. Sachar RK, Kaur N, Soni RK, Dhat R, Singh H. Energy consumption during pregnancy \& its relationship to birth weight: A population base study from rural Punjab. Indian Journal of Community Medicine. 2000;25(4):166-9.

39. Chandra SM, Vijaya AN, Maheshwar D. Mallapur. Factors Affecting Birth Weight of a Newborn. A Community Based Study in Rural Karnataka India. 2012;7(7):1-4.

40. Kapoor SK, Kumar G, Pandav CS, Anand K. Incidence of Low Birth Weight in Rural Ballabgarh, Haryana. Indian Pediatrics. 2001;38:271-5. PMid:11255304.

41. Biswas R, Dasgupta A, Sinha RN, Chaudhuri RN. An Epidemiological Study of Low Birth Weight Newborns in the District of Puruliya, West Bengal. Indian Journal of Public Health. 2008;52(2):65-71. PMid:19125537. 